Article

\title{
Representations of Shylock in Arnold Wesker's The Merchant, Howard Jacobson's Shylock Is My Name and Clive Sinclair's Shylock Must Die
}

\author{
David Brauner
}

\section{check for} updates

Citation: Brauner, David. 2021. Representations of Shylock in Arnold Wesker's The Merchant, Howard Jacobson's Shylock Is My Name and Clive Sinclair's Shylock Must Die. Humanities 10: 59. https://doi.org/ 10.3390/h10020059

Received: 3 March 2021

Accepted: 22 March 2021

Published: 25 March 2021

Publisher's Note: MDPI stays neutral with regard to jurisdictional claims in published maps and institutional affiliations.

Copyright: (c) 2021 by the author. Licensee MDPI, Basel, Switzerland. This article is an open access article distributed under the terms and conditions of the Creative Commons Attribution (CC BY) license (https:// creativecommons.org/licenses/by/ $4.0 /)$.
Department of English Literature, The University of Reading, Reading RG6 6AA, UK; d.brauner@reading.ac.uk

\begin{abstract}
Given the centrality of Shakespeare to the Western canon and, more specifically, to the idea of a national English literary tradition, and given that Shylock is one of his most (in)famous creations, it is hardly surprising that he has proved irresistible to a number of Anglo-Jewish authors. Attempts to rehabilitate Shylock and/or to reimagine his fate are not a recent phenomenon. In the post-war era, however, the task of revisiting Shakespeare's play took on a new urgency, particularly for Jewish writers. In this essay I look at the ways in which three contemporary British Jewish authors-Arnold Wesker, Howard Jacobson and Clive Sinclair-have revisited The Merchant of Venice, focusing on the figure of Shylock as an exemplar of what Bryan Cheyette has described as "the protean instability of 'the Jew' as a signifier". Wesker, Jacobson and Sinclair approach Shakespeare's play and its most memorable character in very different ways but they share a sense that Shylock symbolically transgresses boundaries of time and space-history and geography-and is a mercurial, paradoxical figure: villain and (anti-)hero; victim and perpetrator; scapegoat and scourge. Wesker's play is more didactic than the fiction of Jacobson and Sinclair but ultimately his Shylock eludes the historicist parameters that he attempts to impose on him, while the Shylocks of Shylock is My Name and Shylock Must Die transcend their literary-historical origins, becoming slippery, self-reflexive, protean figures who talk back to Shakespeare, while at the same time speaking to the concerns of contemporary culture.
\end{abstract}

Keywords: Shylock; The Merchant; Shylock is My Name; Shylock Must Die; Arnold Wesker; Howard Jacobson; Clive Sinclair

Given the centrality of Shakespeare to the Western canon and, more specifically, to the idea of a national English literary tradition ${ }^{1}$, and given that Shylock is one of his most (in)famous creations ${ }^{2}$, it is hardly surprising that he has proved irresistible to a number of Anglo-Jewish authors. Attempts to rehabilitate Shylock and/or to reimagine his fate are not a recent phenomenon. ${ }^{3}$ In the post-war era, however, the task of revisiting Shakespeare's play took on a new urgency, particularly for Jewish writers. In this essay I will look at the ways in which three contemporary British Jewish authors-Arnold Wesker, Howard Jacobson and Clive Sinclair-have revisited The Merchant of Venice, focusing on the figure of Shylock as an exemplar of what Bryan Cheyette has described as "the protean instability of "the Jew" as a signifier" (Cheyette 1993, p. 8).

1 For an account of the ways in which Shakespeare became enshrined as the foundational figure of a mythos of Englishness, see (Dobson 1992).

2 Gareth Armstrong's claim that "there is more written about Shylock than any other Shakespearean character apart from Hamlet" seems entirely plausible, albeit difficult to verify (Armstrong 2004, p. 210). It might be added that Shylock is the only Shakespeare character whose name has entered the language, both as a verb and a noun (in both cases it is a pejorative slang term, meaning to lend money at extortionate rates of interest and to be an unscrupulous businessman, respectively).

3 In the middle of the nineteenth century, for example, Edmund Kean hatched a plan to extend his most famous role by staging a play called "The After-Life of Shylock", whose final scene would have shown its hero "visiting Belmont as a pedlar, with a sack of lemons on his back" (Gross [1992] 1994, p. 151), while in 1923, St John Ervine actually produced a sequel to The Merchant of Venice, set 10 years after the end of Shakespeare's play. Unlike Kean, however, who envisaged Shylock enduring a life of humility and poverty, in Ervine's The Lady of Belmont Shylock has become "a senator, a friend of the Duke, a merchant who is twice as wealthy as he was before" (229). 
The fact that Shylock is repeatedly referred to in Shakespeare's play as "the Jew" suggests both the endemic antisemitism of the Venice in which the play is set and that, in terms of the play's own symbolic imaginary, he is a representative figure. This is never clearer than in Shylock's "Hath not a Jew eyes?" and Portia's "quality of mercy" speeches, the two most celebrated passages in the play. In the former, Shylock appeals for sympathy not on the basis of his individual plight but by invoking a universalist view of humanity, while at the same time, the insistent rhetorical emphasis on the word "Jew" emphasises the limits of such an inclusive humanist ideal. In the latter, Portia contrasts the implicitly Christian virtue of "mercy" with the implicitly Jewish privileging of "justice", concluding by appealing to Shylock to demonstrate his humanity in terms that ironically deny him that very same humanity, concealing in the cloak of a claim for clemency a punitive threat: "Therefore, Jew,/Though justice be thy plea, consider this,/That, in the course of justice, none of us/Should see salvation" (IV:I 186-189, my italics).

In a foreword to his theatrical monologue, "Shylock", the Canadian Jewish actor and playwright Mark Leiren-Young reflects on his experiences of playing the role in different productions of The Merchant of Venice, first playing Shylock "as a clown ... an 'ethnic' fool" before reprising the role as "a wounded Jew, a victim of anti-Semitism who was crying out for acceptance" (Leiren-Young 1996, p. 5). He then explains that the rationale for this later interpretation of Shylock as more sinned against than sinning was that "when the Venetians abused Shylock, we're meant to see how ugly and hypocritical they are and how any evil within Shylock is all because of the way he's been treated by the insensitive Christians" before summarily dismissing this as "a wonderful argument" but "[a]bsolute bullshit" (Leiren-Young 1996, p. 6). Bullshit or not, it is an argument that has been mobilised in many productions of the play (from Edmund Kean's landmark performance in 1814 to Trevor Nunn's 1999 production set in Weimar, Germany, starring Henry Goodman) and that was plainly articulated in 1879 by the Anglo-Jewish historian Israel Davis, who insisted that Shakespeare's purpose was to demonstrate that "if the Jew had been treated in a better way, he would have been a better man" (quoted in Gross [1992] 1994, p. 155).

On the other hand, many Anglo-Jewish readers and critics have seen in the play little more than a restatement of the antisemitism that Anthony Julius has argued has a peculiarly vicious British strain. ${ }^{4}$ For Julius, The Merchant of Venice is at its core "a blood libel narrative" and Shylock's "Hath not a Jew eyes?" speech is, far from being an eloquent expression of the dignity to which all humans are entitled, "full of self-pity", confirming his status as a "ludicrous ... ignominious villain" (Julius 2010, pp. 179, 190). In the earliest study of the figure of the Jew in English literature, written on the eve of the Second World War, Montagu Frank Modder steers a middle course, arguing that while Shylock conforms to (antisemitic) type to the extent that he "is extravagant in the fierce love of money and wolfish in the thirst for revenge" Shakespeare's "audience is made to see that, in a great measure, the Jew's behaviour is due to his treatment at the hands of an intolerant Christian community" (Modder [1939] 1960, p. 29). In his study of the same topic, written three decades later, Harold Fisch comes to much the same conclusion, suggesting that "[a] true understanding of Shakespeare's play allows us to see Shylock both as the heir of the monstrous, bloodthirsty, usurer-murderer of medieval legend ... and also as Shakespeare's serious study of the Jewish problem imaged in a figure of tragic dimensions, hated and hating, but above all things, human" (Fisch 1971, p. 32). For Fisch, Shylock is also "a man of the new world, vital, energetic, realistic", exposing the archaic values of the "moonlit world of medieval enchantment" (37). In some respects, this characterisation of Shylock anticipates Arnold Wesker's play, The Merchant (1976), published six years after Fisch's book.

Wesker was an Anglo-Jewish playwright and political activist best known for his "kitchen sink" dramas of the 1950s. However, he devoted a number of years in the mid-

4 Julius also implicitly locates The Merchant of Venice as an originary site for antisemitism by citing, without any contextualisation, as one of four epigraphs to his book, a passage from Philip Roth's novel Operation Shylock (1993), in which the bookseller-turned-Mossad agent, David Supposnik, argues that "[I]n the modern world, the Jew has been perpetually on trial ... and this modern trial of the Jew ... begins with the trial of Shylock" (Julius 2010, n.p.). 
1970s to writing and staging a rewriting of The Merchant of Venice. Initially titled The Merchant and then later Shylock, in a preface to a 1983 edition of the play, Wesker attributes his impulse to revise Shakespeare's play partly to a sense of unease at its contemporary resonances - "I revere Shakespeare ... But nothing will make me admire it [The Merchant of Venice], nor has anyone persuaded me that the holocaust [sic] is irrelevant to my responses" (Wesker [1976] 1983, p. xlix) —and partly to a desire to correct what he sees as an inauthentic representation of Shylock ${ }^{5}$ :

The real Shylock would not have ... raged against not being allowed to cut his pound of flesh but would have said "Thank God!" The point of writing a play in which Shylock would utter these words would be to explain how he became involved in such a bond in the first place. (Wesker [1976] 1983, p. Liii)

Wesker was not the first writer to argue for the necessity of reinterpreting The Merchant of Venice in the light of the Nazi genocide. More than a decade earlier, for example, W.H. Auden had insisted that "[r]ecent history has made it utterly impossible for the most unsophisticated and ignorant audience to ignore the historical reality of the Jews and think of them as fairy-story bogeys with huge noses and red wigs" (Auden cited in Leeming 1983, p. xxii). Yet, there is a tension between Wesker's desire to write a riposte to Shakespeare informed by a post-Holocaust sensibility (and hence, inevitably to read the play anachronistically) and his desire to reconstruct what he sees as a historically authentic version of Shylock. The notion that one might imagine a "real" version of a fictional character is intrinsically problematic, but it is further complicated by Wesker's explicitly didactic purpose. As Robert Wilcher puts it, "As a humanistic sermon, The Merchant has much to recommend it. As a play, it lacks bite; even though it ends sadly, it leaves one with a predominant sense of wishful thinking" (Wilcher 1991, p. 113). On the other hand, Wilcher observes, justly, that the play resonates with "something of the representative authority and imaginative power of myth" (119) and Efraim Sicher praises the way in which "Shylock's silence and obduracy in his insistence on the bond become a proud self-sacrifice to defend the interests of the Jewish community" (Sicher 1985, p. 80) in The Merchant. Ultimately, Wesker's Shylock is no more an authentic portrait of a Jew living in the ghetto of 16th-century Venice than Shakespeare's-but this is not to the detriment of the play. On the contrary, it is Shylock's protean slipperiness-earnest and ebullient, passionate and overbearing, but with a melancholy streak - that brings the play to life.

The most radical change Wesker makes to Shakespeare's play is to represent Shylock and Antonio as best friends rather than bitter adversaries. There were precedents for this-notably, the American poet Louis Untermeyer's sequel The Merchant of Venice Act VI, in which Shylock and Antonio become business partners ${ }^{6}$ - but Wesker goes further than his precursors. Whereas the protagonist of Ludwig Lewisohn's The Last Days of Shylock (1931) claims that, had he been permitted to proceed to the execution of his bond, he would only have inflicted a superficial wound on Antonio, ${ }^{7}$ in Wesker's play he never nurses any hostility towards the merchant. Instead, the "merry bond" is conceived collaboratively, in a satirical spirit (Shylock and Antonio giggling together like mischievous schoolboys) as a way of mocking the Venetian law that all transactions between Jews and Christians had to be formalised by contract.

When it transpires that Antonio cannot repay Shylock's loan and will therefore default on the terms of the contract, it is the merchant, not the moneylender, who insists that it must be honoured:

\footnotetext{
5 Wesker also cites his experience of seeing Laurence Olivier's “oi-yoi-yoi portrayal” of Shylock in Jonathan Miller's production of Shakespeare's play at the National Theatre in 1973 as the catalyst for a revelation of what he saw as the "irredeemable anti-semitism" of The Merchant of Venice (L).

See (Gross [1992] 1994, p. 271).

7 See (Gross [1992] 1994, pp. 271-72).
} 
Not only is your race a minority, it is despised ... Your life, the lives of your people depend upon contract and your respect for the laws behind the contract ... The law, Shylock, the law! For you and your people, the bond-in-law must be honoured. (Wesker [1976] 1983, p. 25)

In Wesker's play, then, it is Antonio rather than Shylock who insists on the inviolability of the bond by harping on "the law'. Yet, by making Antonio a critic, rather than the play's chief perpetrator, of antisemitism (as he is in Shakespeare's play)—by having him kiss Shylock rather than spit on him-Wesker arguably weakens the force of Shylock's predicament. In Shakespeare's play, Shylock must fight his corner alone, whereas in The Merchant, he has both Antonio and Portia as allies. In spite of Antonio's insistence that Shylock's "race ... is despised", there is a danger here that the play itself ends up downplaying the historical realities of antisemitism through its realignment of the main characters' loyalties.

Likewise, the changes that Wesker makes to the Jessica sub-plot-in The Merchant she repents of her elopement with Lorenzo, coming to despise her husband's antisemitism, and never steals any of her father's possessions or money-arguably vitiate her betrayal and hence, again, diminish the sense of Shylock's isolation that is so important in The Merchant of Venice. In Wesker's play, it is Lorenzo who delivers the "Hath not a Jew eyes?" speech, prompting an indignant response from Shylock:

I do not want apologies for my humanity. Plead for me no special pleas ... If I am unexceptionally like any man, then I need no exceptional portraiture ... My humanity is my right, not your bestowed and gracious privilege. (76-77)

Shylock's scathing critique of the speech for which his original incarnation is most celebrated, represents an uncompromising rejection of the idea that it is an indictment of antisemitism avant la lettre but, at the same time, it appeals to an equally ahistorical idea of human rights. Ultimately, The Merchant is a paradoxical play; both a historicist critique of Shakespeare's play (which is to say, an attempt to contextualise the action of the play in social and historical terms by, for example, emphasising the conditions in which Jews in 16th-century Venice lived and worked) and also a revisioning of it through the lens of contemporary concepts such as antisemitism and feminism. As Wilcher points out, Wesker attempts to imbue the play with a sense of historical authenticity by invoking the history of antisemitism through references to real events, such as "the public burning of Hebrew books on 12 August 1553, the massacres of Jewish communities during the Middle Ages ... the segregation of the Jews of Venice in the Ghetto" (113). ${ }^{8}$ Likewise, Wesker emphasises the economic realities of the Venice in which Shakespeare's play and his own are set. As Gavin Armstrong points out, in The Merchant of Venice, all we learn about Shylock's countryman, Tubal, is that he is "[r]ich and Jewish" (Armstrong 2004, p. 71). In The Merchant, by way of contrast, Tubal sets out plainly the poverty and dangers of life in the ghetto that are never mentioned in Shakespeare's play: "sometimes there's barely pennies in the Ghetto. For days we're all borrowing off each other, till new funds flow in. Only fourteen hundred souls, remember ... trapped in an oppressive circus with three water wells and a proclivity for fires" (Wesker [1976] 1983, vol. 1, p. 3). Yet, at the same time, his Shylock transcends this historical context, resembling an Enlightenment intellectual more than a Renaissance businessman. The philosophical conversations he has with Antonio anticipate those shared by the protagonists of another post-war rewriting of The Merchant of Venice by another post-war Anglo-Jewish author: Shylock is My Name by Howard Jacobson.

\footnotetext{
8 In this respect, Wesker anticipates Caryl Phillips' The Nature of Blood (1997), which offers a fictional account of an infamous blood libel trial in 1480 in Portobuffole, a small district of Venice, in which a group of Jewish moneylenders was framed, tried and executed for the murder of a Christian child by the community after their debtors were unable to repay them the money they owed. This story provides historical context for two other strands of the novel: the narrative of a traumatised Holocaust survivor, and a retelling of Shakespeare's Othello, which features an episode in which the protagonist visits the Jewish ghetto. Like Wesker, Phillips emphasises the legalistic framework of the Venetian state for ironic effect: "The Most Serene Republic of Venice not only boasted of its severe justice, but was also proud of its flawless procedure ... no one ... could be condemned to death unless his crimes could be verified by proof or confession" (Phillips [1997] 1998, p. 96).
} 
Howard Jacobson's investment in Shakespeare has been evident from the start of his career. His very first book, Shakespeare's Magnanimity (1978), was a study of four of the tragedies, co-authored with Wilbur Sanders, in whose memory Shylock is My Name is dedicated. Jacobson's 14th novel was the result of a commission by the Hogarth Press, who decided to commemorate the 400th anniversary of Shakespeare's death by asking a number of contemporary novelists to rewrite a Shakespeare play. For Jacobson, this was something of a poisoned chalice because of the history of antisemitism associated with The Merchant of Venice. Jacobson summarises Shakespeare's Shylock as "[a] usurer who exacted interest mercilessly; a tyrannical father who made his daughter's life a living hell; an inflexible creditor who put the letter of the law before the spirit of forgiveness and was ready to spill blood in pursuit of his bond ... the very image of the Jew who had demanded Jesus's crucifixion and wandered the Earth accursed ever since" (Jacobson 2016b). He goes on to acknowledge that "generations of actors played Shylock ... as the medieval stereotype of the grasping and vindictive, hook-nosed, knife-wielding Jew whom no appeal to a common humanity could soften" and that the Nazis exploited this tradition, ensuring that "The Merchant of Venice was performed in the theatres of the Third Reich repeatedly" (Jacobson 2016b). Yet for Jacobson, unlike Wesker, the temptation to "save Shylock from his own creator" is to be resisted, even, or especially, in the context of the history of the Holocaust. For Jacobson, the play confirms the antisemitic worldview of those who already harbour anti-Jewish sentiments but is not itself antisemitic.

At one point in Shylock is My Name, Strulovitch, a contemporary art dealer whose life mirrors Shylock's in various ways, speculates that Shakespeare might have had Jewish ancestry himself. Far from spreading what he calls "the ancient stain" (Jacobson 2016a, p. 15) of antisemitism, and so ultimately facilitating the Holocaust, Strulovitch speculates that Shakespeare might have conjured up Shylock as a way of recuperating a Jewish heritage that the "Sh" at the start of his own name might have both hinted at and occulted (might it have been changed from Shapiro, he wonders), and as a way of restoring a virtual Jewish presence to the otherwise "Judenfrei Elizabeth England" (8). Strulovitch's anachronistic use of the Nazi term to describe the absence of Jews from Shakespeare's world (as a consequence of the expulsion of the Jews from England in 1290) paradoxically highlights the differences between the 20th-century genocide and the medieval policy of exclusion and serves as an implicit warning against retroactively indicting Shakespeare's play for inciting crimes against Jews.

On the other hand, Jacobson's novel dislocates Shylock from his historical context; the Shylock of Shylock is My Name has read Philip Roth and is our contemporary as much Shakespeare's. He and Strulovitch are doppelgangers, or at least secret sharers. The connections between the two men are evident from the start: they meet in a cemetery, where they are both mourning Leahs-in Strulovitch's case his mother, in Shylock's his wife; they both have daughters who elope with Gentile men who are not gentlemen; they both become embroiled in a conflict with professional rivals, which escalates into a feud and leads to a trial of sorts. ${ }^{9}$ Rather than slavishly following Shakespeare's plot, Jacobson playfully subverts it. Instead of creating characters who correspond precisely to the dramatis personae of The Merchant of Venice, Jacobson conflates certain characters. For example, D'Anton, Strulovitch's antagonist, fulfils the role not just of Antonio but also Balthazar, faithful servant to Portia, while Gratan Howsome, the lover of Strulovitch's daughter, Beatrice, is an amalgamation of Lorenzo and Gratiano. In other cases, such as the extravagantly-named wealthy heiress, Anna Livia Plurabelle Cleopatra a Thing of Beauty is a Joy Forever Christine Shalcross (Plury, for short), who owns a "Porsche Carrera" (22), the brand name of the car that is a homophone for the heroine of The Merchant of Venice, characters in the novel are modern-day counterparts of their originals. Yet the relationship between Shylock and Strulovitch is more complex and ambiguous; rather than standing

\footnotetext{
9 Whereas Shylock resents Antonio for lending money gratis, thereby lowering the rates of interest that he can charge, Strulovitch and his rival D'Anton are both art collectors, and Strulovitch owns a painting which D'Anton has promised to secure for his friend, Barnaby, so that he can present it to his amour, Plury.
} 
in for Shylock, Strulovitch co-exists with him. Whether Shylock is a ghost, a revenant, a version of the Wandering Jew, or a golem of sorts, born of Strulovitch's imagination, is never entirely clear. ${ }^{10}$ Nor is it clear whether Strulovitch is doomed to reprise Shylock's fate or overturn it; to redeem, rehabilitate, vindicate or deviate from his avatar, whose avatar he also is.

Any contemporary rewriting of a Shakespeare play is also implicitly a (re)reading of its source, but Shylock is My Name also engages explicitly, and in detail, with a number of the most controversial features of Shakespeare's play. For example, it features a compelling defence of Shylock's infamous exclamation "My ducats, my daughter", which has conventionally been interpreted as evidence that he is as distressed by the theft of the former as by the elopement of the latter: "in the outrage of loss, objects and people lose their delineation. The robbed commonly speak of violation, feeling the theft of things as keenly as an attack on their person" (52-53). The word "violation" is particularly resonant in the context of a play in which Shylock is stripped of all his rights, possessions and faith, and in the context of a novel in which Strulovitch, in revenge for what he sees as the violation of his daughter (she is only 15 when Gratan begins an affair with her), threatens to violate Gratan's person-and D'Anton's, since he offers to forfeit his foreskin in lieu of Gratan's if the latter fails to honour his contract with Strulovitch. The phrase "attack on their person" also seems to allude to Antonio's ambiguous expression of friendship for Bassanio (Barnaby in Jacobson's novel), a line that is pointedly paraphrased in Shylock is My Name: "His purse, his person, his extremest means, lay all unlocked to his young friend's occasions" (132). The word "unlocked", in turn, returns us to the idea of theft-to Shylock's name, to his vain attempts to protect himself and his household, in locking his doors and attempting to lock away his daughter-and to the connection in the play between marriage rings as "objects" that can be stolen or traded, and as symbolic representations of female genitalia, whose "loss" involves a violation of the person, or at least the prising open of something that has been sealed. ${ }^{11}$ Finally, Strulovitch's sympathetic interpretation of lines that have conventionally been adduced as evidence of Shylock's materialism complement Shylock's own deconstruction of Lorenzo's praise of Jessica:

She was not daughter to her father's manners, she said, but Lorenzo, the rascal who pilfered her, along with those who conspired in her misappropriation, could not stop commenting on her difference from the man she was ashamed to call father, her gentler (for which read more Gentile) disposition ... the fairness of her looks ... and when all you can remark is difference then all you are aware of is similarity. (84)

Shylock's use of "pilfered" and "misappropriation" might ostensibly seem to reinforce the notion that he is guilty of objectifying - and commodifying-his own daughter, but it might also suggest that it is Lorenzo and his co-conspirators who see her as a prize to be won (as Bassanio does of Portia), and who value her not for any personal qualities but as one of her father's valuables. Furthermore, Shylock suggests, this value is likely to depreciate or collapse altogether because it is based on a superficial appreciation of her difference from her father, which is expressed so insistently as to imply, paradoxically, that they will "never reconcile themselves to the fact that she was Jewish" (84). To adapt a line from another Shakespeare play, Lorenzo doth protest too much.

It is this intricate, intertextual interplay that makes Shylock is My Name one of Jacobson's most richly-textured novels. There are penetrating discussions of many other episodes from Shakespeare's play and the debates that they have inspired. For example, Strulovitch cross-examines Shylock as to the status of Tubal's report to Shylock of Jessica's spending spree ("Your daughter spent in Genoa, as I heard, in one night four score ducats" [201];

10 What is clear is that Shylock shares Strulovitch's consciousness in some way, so, for example, when the former asks the latter "How many jungle Jews do you know?" and the narrator reports that "Offhand, Strulovitch could only think of Johnny Weismuller" (Jacobson 2016a, p. 51), Shylock immediately dismisses the thought, asserting that "Tarzan ... wasn't one of us" (51-52) even though Strulovitch has not said anything aloud.

11 Hence the slang term "clam" (sometimes "bearded clam"), a euphemism for the vagina in the United States. 
"Did you ever consider that Tubal might have lied to you?" (202); "What if he conjured the monkey out of his own Jewish terrors?" (203)). However, the novel repeatedly returns to two related questions. Did Shylock intend his "merry jest" in earnest from the outset? And, if he had been allowed to proceed, would he have actually murdered Antonio? Rather than providing definitive answers to these questions, Shylock explores their larger implications, gently chiding Strulovitch for seeking "an explanation for what cannot be explained" (151) and posing his own, unsettling questions: "What is intention? Whatever his intention, would Abraham have gone on to kill Isaac?" (178); "If you prick us, do we not bleed, but if we prick back do we not shed blood?" (182). The implications of drawing attention to the structural similarities between the trial scene and the Akedah are radical. Rather than reviving the old canard of the Jew as Christ-killer, it frames the climactic scene in Shakespeare's play in terms that align Shylock with the great patriarch and founder of monotheism, Abraham, and suggests that he is an instrument of divine agency, rather than a would-be deicide. However, it also recasts Antonio as an innocent child, a role that is at odds with Shylock's argument that Antonio was a self-regarding masochist, "undeserving" of "[t]he tragedy he had always sought out for himself" (151). Similarly, the modification of one of the most famous lines from the play-from one of the most famous speeches in the English canon-highlights a troubling double standard: that Shylock, and by extension Jews in general, are granted humanity only while they are victims, not when they are aggressors. As Jacobson put it rather more pithily, in Roots Schmoots, it is "an immutable truth [that] the only good Jew is a tragic Jew" (Jacobson 1993, p. 190).

In addition to these reinterpretations of Shakespeare's text, Shylock is My Name also alters the plot of the original play in a number of ways. Perhaps the most radical of these changes is to transform Shylock's demand for a pound of Antonio's flesh into a demand on the part of Strulovitch that Gratan Howsome undergoes a circumcision if he is to marry his daughter (with whom he elopes earlier in the novel), which in turn becomes a sacrifice that D'Anton, Howsome's sponsor, volunteers to make. As it turns out, D'Anton has already been circumcised, so no blood is shed, but in raising this threat and incorporating it into a special episode of Plury's television series The Kitchen Counsellor, Jacobson foregrounds the antisemitic tropes that Shakespeare's play invokes. A number of critics have pointed out that Shylock's insistence on his pound of flesh-and indeed Portia's insistence that he cannot shed any blood in extracting it-implicitly invokes the infamous blood libel. ${ }^{12}$ Whereas Shakespeare's play contains "hints ... of a cannibalistic impulse ... [originating from] a dark traditional prejudice ... the accusation that they [Jews] feasted on Christians when they could" (Gross [1992] 1994, p. 29), in Jacobson's novel, these hints are fleshed out and integrated with another of the submerged threats contained in Shylock's bond: that of enforced circumcision. James Shapiro points out that "[i]n the late 16th century, the word flesh was consistently used ... in place of penis" (Shapiro 1996, p. 122), so that "an occluded threat of circumcision informs Shylock's desire to cut a pound of Antonio's flesh" (114), echoing Theodor Reik's claim that Shylock's threat to excise a pound of flesh from Antonio is "not only ... a symbolic castration but ... a symbolic circumcision too" (Reik quoted in Gross [1992] 1994, p. 304).

Jacobson's novel is, like Wesker's play, flawed-the satire at the expense of celebrity culture is rather heavy-handed-but, again like Wesker's play, its reinvention of Shylock himself is a triumph. In Shylock is My Name he emerges as a brilliant critic of the play that gave him birth, and of the ambivalence with which other Jews regard it, and themselves: "These Jews ... They don't know whether to cry for me, disown me or explain me. Just as they don't know whether to explain or disown themselves" (Jacobson 2016a, p. 194). He is by turns avuncular, mordantly witty, sceptical, detached, compassionate and sanguinein short, slippery and protean. He is also a liminal figure, both historically (straddling

12 John Gross argues that "behind the usurer enforcing his bond, there looms that ultimate bogeyman, the Jew intent on shedding Christian blood for its own sake" (Gross [1992] 1994, p. 29) and James Shapiro goes further, suggesting that the myth of Jewish ritual murder "had a long and special history in England-it remained in circulation even when there were hardly any Jews in the land ... and its popularity (even into the present century) reveals much about entrenched English anxieties about the Jews" (Shapiro 1996, p. 9). 
Shakespeare's world and our own) and materially (he seems to be part ghost, part dybbuk and part revenant). In this respect, he prefigures the Shylock figures who populate Clive Sinclair's final collection of stories, Shylock Must Die (2018).

Clive Sinclair's interest in Shylock goes back at least as far as his piece "The Ghetto of Venice", published in the Times Literary Supplement in 2016, in which he gives an account of "the climax of a summer of events orchestrated by Professor Shaul Bassi of Ca'Foscari University to mark the quincentennial of [the foundation of the first] Ghetto" (Sinclair 2016). Among these events is a rendition of Shylock's "Hath not a Jew eyes?" speech by F. Murray Abraham in the Chapter Room of the Scuola Grande di San Rocco, in which Shylock becomes "the Appellant in a Mock Appeal against the play's original verdict: no pound of flesh, no repayment; on the contrary, forfeiture of property and fortune, and forced conversion" (Sinclair 2016). Later, Shylock's case is prosecuted and judged by a number of legal luminaries. Mario Siragusa, representing Antonio and the Venetian state, reminds the audience of academics, lawyers, authors and laymen that "it would not be appropriate to approach the matter with our contemporary sensibility, schooled by history to the atrocious outcome of anti-Jewish prejudice and persecution in the 20th century" (Sinclair 2016), as though responding to Wesker's play. But ultimately, the judges' unanimous verdict is one that would have cheered Wesker; Ruth Bader Ginsburg explains the court's ruling that the bond ought to be "dismissed as a jest, one that no court in its right mind would grant", so that "Antonio is ordered to repay his loan (though he is spared interest on it); Shylock's fortune is restored and his conversion revoked, on the grounds that Antonio, as defendant, had no right to demand it" (Sinclair 2016).

This trip to Venice clearly inspired at least some of the material that finds its way into Shylock Must Die ${ }^{13}$ but ultimately, Sinclair, unlike Wesker and Ginsburg, is not interested in setting the record straight but rather in using Shakespeare's play-and Shylock in particular-as a point of departure for exploring some of the recurring preoccupations of his career. The title story is narrated by Tubal, a minor character from Shakespeare's play who helps Shylock raise the 3000-ducat loan for Antonio and is sent to try to retrieve Shylock's daughter, Jessica, after she elopes with Lorenzo. But in this reimagining of the events of Shakespeare's play, Tubal is a private eye, recalling the occupations of previous Sinclair protagonists, such as Joshua Smolinksy, a recurring figure in Sinclair's first two collections of stories, Hearts of Gold (1979) and Bedbugs (1982), who is also a sort of authorial alter ego (Sinclair's father changed his name from Smolinksy to Sinclair). The metafictional references to Sinclair's own biography in "Shylock Our Contemporary" and "Shylock's Ghost" echo the self-reflexive games of Sinclair's novel Blood Libels (1985), and the mixture of metaphysics and middle-eastern politics in "If You Tickle Us" and "Ain't That The Truth" (which features a golem-turned-American-president with more than a passing resemblance to Donald Trump) is reminiscent of one of Sinclair's most accomplished stories, "Ashkenazia" and his most extravagant novel, Cosmetic Effects (1989).

"Shylock Must Die", the title story of Sinclair's collection, provides a backstory to Shakespeare's play, in which Bassanio kills Zebulum, the son of a friend of Shylock's, a Rabbi with a gambling problem, when he is unable to repay a loan to Bassanio's friend, Antonio (the rabbi gambles away half of the money that Shylock gives him to cover the debt, so that he is only able to offer $50 \%$ of the money he owes). It also reverses the traditional dynamic of the tyrannical Jewish patriarch and the virtuous Jewish girl—what Harold Fisch calls the "polarisation" of "the Jewish soul Father and Daughter" (Fisch 1971, p. 31). In Sinclair's story, Shylock is a generous friend and loyal parent, who sends Tubal to rescue his daughter from Lorenzo, who plans to sell her into the white slave trade, while Jessica is a manipulative femme fatale who ensnares Tubal in her web, ordering him, in the final words of the story, to kill her own father.

13 Some of the events that Sinclair describes in his article are fictionalised in "Shylock Our Contemporary", one of the stories in Shylock Must Die, in which a version of Professor Bassi appears as one of the characters. 
Whereas in The Merchant of Venice, Antonio's life is imperilled after he is unable to repay Shylock's loan but is ultimately saved by Portia's intervention, in Sinclair's story, Tubal-the narrator, a private investigator hired by the Rabbi to help him rescue his son from his Christian captors, who have kidnapped him as collateral-is unable to prevent his murder. The explanation Bassanio offers for "slic[ing] open the boy's belly, as if he were a trout" invokes both the accusation of deicide, which has been the cornerstone of antisemitism through the ages, and the sophistical reasoning that Portia uses in Shakespeare to invalidate Shylock's bond: "I have taught the Christ-killers a lesson ... For half the money, they get the boy, but drained of blood; that is forfeit, for this earthly and that other eternal debt" (7). ${ }^{14}$ Filled with remorse for having failed to save Zebulum's life, Tubal concludes that Bassanio "acted with impunity because he guessed-correctly-that the Rabbi's bodyguard was unarmed" and resolves to carry a dagger, in the belief that "[t]he weapon sent out a message: If you prick us, you too will bleed" (8). Just as Bassanio's justification for killing the Rabbi's boy inverts the purpose of Portia's insistence that Shylock can only claim his pound of flesh if none of Antonio's blood is shed in the process (by doing so she saves Antonio's life, whereas Bassanio takes the boy's life), so Tubal turns Shylock's famous insistence on the human vulnerability of Jews into a threat of reprisal against those who exploit that vulnerability. Yet, in another sense, Sinclair's repurposing of these episodes from The Merchant of Venice is more a reiteration than a subversion of their original meaning. After all, if Portia's pedantry is initially deployed redemptively-to spare Antonio-it is soon turned into an engine of persecution, as she warns Shylock that if he "shed[s]/One drop of Christian blood" (4.1: 304-5) all that he owns will be appropriated by the state and that, in any case, as "an alien" who has sought "the life of any citizen" (4.1: $343,345)$, his life itself is forfeit unless the Duke grants him clemency. Similarly, what is often overlooked in the frequent citation of Shylock's rhetorical question "If you prick us, do we not bleed?" (3.1: 47-8) is that what begins as a plea for tolerance ends as a vow of vengeance: "And if you wrong us, shall we not revenge?" (3.1: 49).

What emerges clearly from the juxtaposition of these episodes is the intractable otherness of the Jew in Venetian law and culture. As her repeated use of "Jew" to address Shylock in the trial scene in Shakespeare's play implies ${ }^{15}$, Portia's recourse to the legal small print is primarily a flimsy rationalisation, a confirmation of the pre-existing disenfranchisement of the Jewish population in Venice. They are not "citizens" with the rights of Venetians but rather "aliens" who are allowed to trade in the city only under sufferance and with severe restrictions, of which their physical segregation in the ghetto is only the most obvious example. Shylock's grave error is to assume that the laws of Venice offer him any satisfaction or protection, that they will uphold his bond and enable him to enact his vengeance. In one of the later stories in Sinclair's collection, "Shylock Our Contemporary", a Shakespeare scholar points out that the "Alien Statute" to which Portia refers is her own invention, but that it chillingly anticipates "Mussolini's Racial Laws, which deprived Shylock's co-religionists of their rights, jobs, assets and lives" (127). At any rate, as John Gross points out, "[u]ntil the end of the eighteenth century no Jew ... could become a Venetian citizen" (Gross [1992] 1994, p. 37). The purpose of Venetian law was to protect the rights, property and lives of its Christian citizens; by implication, Venetian Christians were able to shed the blood of Jews with impunity and if Jews had the temerity (or naivety) to seek redress for grievances under the law, they were likely to be sacrificed in the name of the justice to which they appealed.

Whereas Wesker rehabilitates Shylock, arguably resorting to uncomfortable narrative contortions of his source in order to do so, and Jacobson's Shylock appropriates (or, as

14 The label of "Christ-killer" has an additional resonance in the context of The Merchant of Venice, in which, as John Gross points out, early audiences watching Antonio "brought from prison, and led like a lamb to the slaughter," would inevitably have "been reminded of the Man of Sorrows" (Gross [1992] 1994, p. 93).

15 As John Gross points out, in the trial scene, all the other characters "repeatedly address him [Shylock] as 'Jew', or speak of him as 'the Jew' in his presence. They are not only closing ranks against him; they are also letting him know that his personal identity is of no account." (Gross [1992] 1994, p. 64) 
he sees it, reclaims) the "quality of mercy" as a Jewish value, Sinclair contextualises, but does not attempt to soften, Shylock's intentions. Addressing the question of whether or not Shylock would "really have plunged the blade through flesh to beating heart", Tubal concludes that "he was by then a passenger of the drama and would not have been able to stay his hand" (Sinclair 32), an observation that seems, obliquely and metafictionally, to acknowledge that the actions of the characters in "Shylock Must Die" are ultimately determined by the events of Shakespeare's play. In this respect, Sinclair departs from Ludwig Lewisohn's novel The Last Days of Shylock (1931), in which the eponymous protagonist reflects, in direct contradiction of the evidence of Shakespeare's play, that "if the court had upheld his claim, his knife would not have gone very deep into the bosom of his adversary" (Gross [1992] 1994, p. 272).

Sinclair finishes "Shylock Must Die" by revisiting another of the most infamous episodes in Shakespeare's play. Jessica asks Tubal, whom she has seduced and manipulated into killing Lorenzo, "Is it not true that he [Shylock] said to you: "I would my daughter were dead at my foot ... " Or were his words misrepresented?" (40). In Shylock is My Name, Shylock's words are echoed in Strulovitch's recollection of how his father had disowned him for marrying out of his Jewish faith, "Better you were dead at my feet" (Jacobson 2016a, p. 2), and Shylock himself counsels Strulovitch to show compassion to his own unruly daughter. But in Sinclair's story, Jessica's rhetorical questions close down any attempt to reinterpret Shylock's words, offering an implicit rebuke to anyone who might try to mitigate her father's implacable expression of hatred. Unlike The Merchant, in which Jessica bitterly regrets her elopement, and Shylock is My Name, in which Shylock reproaches himself for his estrangement from his daughter, "Shylock Must Die" imagines a deepening of the rift between father and daughter, which culminates in Jessica plotting the death of her own father.

If "Shylock Must Die" finishes with the prospect of a realisation of the metaphorical death that Shylock's near-final words in Shakespeare's play ("I am not well") seem to presage (IV:I, p. 389), the final story in the collection, "Shylock's Ghost", offers a more meditative, oblique reflection on The Merchant of Venice, in which Shylock, as he does in Jacobson's novel, achieves a ghostly afterlife of sorts. ${ }^{16}$ Neither Jacobson nor Sinclair was the first Jewish author to imagine Shylock as a spectral presence, floating free from the pages of Shakespeare's play. John Gross observes that for the German Jewish poet and essayist Heinrich Heine, Shylock "was so vivid a presence ... that it was hard to believe that he could not still be found somewhere in Venice, lurking behind a pillar, or haunting the Rialto" (Gross 261). But Jacobson and Sinclair go further than Heine by transplanting Shakespeare's character into contemporary Britain; in the case of the former, into the "golden triangle" of Cheshire; in the case of the latter, into the rather more prosaic milieu of North West London.

"Shylock's Ghost" begins with the narrator informing us that "[m]y son, the movie director, has flown over from LA to shoot a reboot of The Merchant of Venice, at locations in Golders Green and Kenwood", before reflecting on the peripheral role he appears to have in his son's life: "How often do I get to see my son? Not often enough, now that we inhabit different continents. I haunt the sets" (167). This opening sends out mixed messages about the kind of story that this might be. The phrase "my son, the movie director", because of its syntax and its use of the definite article, seems to be a variation on the old Jewish joke for which the punchline is "my son, the doctor". ${ }^{17}$ On the other hand, that father and son now apparently live on "different continents" appears to hint at an estrangement, and the

16 There's no evidence that Jacobson had a direct influence on Sinclair, but it is worth noting that in 2015, when Alan Yentob interviewed Jacobson about the writing of Shylock is My Name in an episode of the occasional television series "Imagine", the film carried the same title as Sinclair's story ("Shylock's Ghost").

17 The one I have in mind goes like this:

A Jewish mother is with her son at the beach, a son of whom she is very proud as he recently passed his medical exams. Within minutes of entering the sea for a swim, he gets pulled under by a huge wave.

Trying to get someone to come to his assistance, she screams, "HELP! HELP! My son the doctor is drowning!"

I have taken this version of the joke from aish.com: https:/ /www.aish.com/j/j/151285305.html (accessed on 10 November 2020). 
fact that the only way the narrator can get to see his son seems to be for him to "haunt" the sets on which he is filming seems to suggest that his presence might not be welcome. At this stage, then, we might expect this to be a tale of domestic realism in which there might be a disclosure of a back story-perhaps details of a falling-out - that will explain the distant relations between the narrator and his son.

As the story develops, however, it becomes increasingly surreal. Emerging "from the underground" in Hendon to revisit the stomping grounds of his childhood, of which he claims to be the "only survivor" (167), the narrator witnesses a brawl between two men, one of whom is dressed in a "long black gown, long black pantaloons, and a red three-cornered hat" (Sinclair 2018, p. 168). The man in the odd costume turns out to be Charles Macklin, who is trying out his disguise as Shylock, and who is gratified to have been mistaken for a Jew by the man with whom he had been fighting. Macklin was the first actor to revive the role of Shylock in Shakespeare's play after an interlude of forty years in which the play was only performed on the English stage in a bowdlerised version by George Granville entitled The Jew of Venice. Macklin was "determined to get away from the comic interpretation [that had become the norm in productions], to stint nothing of the character's ferocity" (Gross [1992] 1994, p. 111) and conducted unprecedented research into the role in an attempt to present an authentic (as he saw it) representation of a 16th-century Venetian Jew. He discovered that Jews in Venice had worn red hats and, according to a contemporary account, "made daily visits to the 'Change and the adjacent coffee-houses, that by a frequent intercourse and conversation with [Jews] ... he might habituate himself to their air and deportment" (quoted in Gross 111). So powerful was Macklin's performance that George II was reputedly "so overwrought by the experience that he could not sleep afterwards" (113), an anecdote that Macklin in Sinclair's story embellishes: "when I presented him [Shylock] ... at Drury Lane, it was said that my performance so terrified George II that he was robbed of sleep for a week" (Sinclair 2018, p. 170).

The story takes another strange turn when Macklin accompanies the narrator on a visit to the latter's old family home, where they meet the latter's long-dead parents. At this stage, the narrator observes that he feels "as though I am trapped in a ghost story" (171-72), a metafictional disclosure that seems to be confirmed by the denouement of the story, in which the narrator returns to his son's film set (where he is directing the trial scene from The Merchant of Venice), blowing him a kiss before confessing that, instead of reciprocating or acknowledging his father's presence, his son "looks right through me, as if I were insubstantial as a Kodachrome" (172). In spite of the ambiguity of this simile (a photograph-for which "Kodachrome" here is a synonym-may invoke the ghosts of the past but is material as they are not), this ending imbues earlier details with new resonances; the references to "inhabiting different continents', "haunt[ing] the sets" and "emerging from the underground" become, retrospectively, clues as to the otherworldly status of the narrator. But the title itself remains rather enigmatic. Does it refer to the shade of Macklin, doing some method acting in the Jewish enclave of Hendon? To the son's film, which aims to "reboot" The Merchant of Venice and therefore, by implication, to reanimate its characters? To the unnamed narrator himself, whose nostalgia miraculously disinters the Hendon of his childhood, with its art-deco cinema showing the iconic western Shane (1953) and its parade of shops selling kosher produce-a butcher's, greengrocer's, a bakery and a delicatessen-and who also seems to conjure up Macklin? The story provides no clear answers but preserves all these possibilities.

At one point, the narrator of Shylock is My Name observes that "the Jewish imagination ... sets no limits to chronology or topography [and] ... cannot ever trust the past to the past" (Jacobson 2016a, p. 5). This seems to be an apt gloss for the three texts I have been discussing. Wesker, Jacobson and Sinclair approach Shakespeare's play and its most memorable character in very different ways, but they share a sense that Shylock symbolically transgresses boundaries of time and space-history and geography-and is a mercurial, paradoxical figure: villain and (anti-)hero; victim and perpetrator; scapegoat 
and scourge. Wesker's play is more didactic than the fiction of Jacobson and Sinclair ${ }^{18}$ but ultimately his Shylock eludes the historicist parameters that he attempts to impose on him, while the Shylocks of Shylock is My Name and Shylock Must Die transcend their literary-historical origins, becoming slippery, self-reflexive, protean figures who talk back to Shakespeare, while at the same time, speaking to the concerns of contemporary culture.

Funding: This research received no external funding.

Institutional Review Board Statement: Not applicable.

Informed Consent Statement: Not applicable.

Data Availability Statement: Not applicable.

Conflicts of Interest: The author declares no conflict of interest.

\section{References}

Armstrong, Gareth. 2004. A Case for Shylock: Around the World with Shakespeare's Jew. London: Nick Hern Books.

Cheyette, Bryan. 1993. Constructions of "the Jew" in English Literature and Society. Cambridge: Cambridge University Press.

Dobson, Michael. 1992. The Making of the National Poet: Shakespeare, Adaptation and Ownership, 1660-1769. Oxford: Oxford University Press.

Fisch, Harold. 1971. The Dual Image: A Study of the Jew in English Literature. London: World Jewish Library.

Gross, John. 1994. Shylock A Legend and Its Legacy. New York: Touchstone. First published 1992.

Jacobson, Howard. 1993. Roots Schmoots: Journeys among Jews. London: Viking.

Jacobson, Howard. 2016a. Shylock is My Name. London: Hogarth.

Jacobson, Howard. 2016b. Shylock and Me. Mail Online. February 6. Available online: https://www.dailymail.co.uk/home/ event/article-3431677/Shylock-reinvents-Shakespeare-s-money-lender-Howard-Jacobson-insists-wasn-t-Bard-anti-semiticmaliciously-misread-him.html (accessed on 12 December 2020).

Julius, Anthony. 2010. Trials of the Diaspora: A History of Anti-Semitism in England. Oxford: Oxford University Press.

Lawson, Peter. 2021. The Didactic Theatre of Arnold Wesker: Didactic, Utopian, Biblical. In A Companion to British-Jewish Theatre since the 1950s. Edited by Malkin Jeanette, Eckart Voigts and Sarah Jane Ablett. London: Bloomsbury Publishing.

Leeming, Glenda. 1983. Commentary. In Arnold Wesker, The Merchant. London: Bloomsbury, pp. xiv-xxxix.

Leiren-Young, Mark. 1996. Shylock. London: Anvil Press.

Modder, Montagu Frank. 1960. The Jew in the Literature of England. New York: Meridian Books \& The Jewish Publication Society. First published 1939.

Phillips, Caryl. 1998. The Nature of Blood. London: Faber \& Faber. First published 1997.

Shapiro, James. 1996. Shakespeare and the Jews. New York: Columbia University Press.

Sicher, Efraim. 1985. Beyond Marginality: Anglo-Jewish Literature after the Holocaust. Albany: State University of New York Press.

Sinclair, Clive. 2016. The Ghetto of Venice. Times Literary Supplement. October 21. Available online: https://www.the-tls.co.uk/articles/ freelance-766/ (accessed on 20 December 2020).

Sinclair, Clive. 2018. Shylock Must Die. London: Halban.

Wesker, Arnold. 1983. The Merchant. London: Bloomsbury. First published 1976.

Wilcher, Robert. 1991. Understanding Arnold Wesker. Columbia: University of South Carolina Press. 